Winter 2009

\title{
Pain, Gain, or Shame: the Evolution of Environmental Law and the Role of Multinational Corporations
}

\author{
Michael Ewing-Chow \\ Darryl Soh \\ National University of Singapore
}

Follow this and additional works at: https://www.repository.law.indiana.edu/ijgls

Part of the Business Organizations Law Commons, Environmental Law Commons, International Law Commons, and the Law and Politics Commons

\section{Recommended Citation}

Ewing-Chow, Michael and Soh, Darryl (2009) "Pain, Gain, or Shame: the Evolution of Environmental Law and the Role of Multinational Corporations," Indiana Journal of Global Legal Studies: Vol. 16 : Iss. 1 , Article 7.

Available at: https://www.repository.law.indiana.edu/ijgls/vol16/iss1/7

This Symposium is brought to you for free and open access by the Law School Journals at Digital Repository @ Maurer Law. It has been accepted for inclusion in Indiana Journal of Global Legal Studies by an authorized editor of Digital Repository @ Maurer Law. For more information, please contact rvaughan@indiana.edu.

\section{$\Psi$}

JEROME HALL LAW LIBRARY

INDIANA UNIVERSITY

Maurer School of Law
Bloomington 


\title{
Pain, Gain, or Shame: The Evolution of Environmental Law and the Role of Multinational Corporations
}

\author{
Michael Ewing-Chow* \& Darryl Soh+
}

\begin{abstract}
The evolution of environmental law in the past century has been linked to the growing acceptance of the notion of collective global responsibility, which entails the notion of sustainable development. At the turn of this century, the focus in environmental law has shifted from the creation of a global framework to deal with environmental problems to that of compliance with these frameworks. As a result, the primary actor of environmental policy has shifted from the state to the corporation. How has environmental law developed so as to encourage compliance by this new primary actor? Conversely, how has the corporation been changed by these developments? This article will trace the historical shift in environmental actors from the early beginnings of environmental law to the challenges faced today. As the multinational corporation has become the primary actor, this article also considers ways in which incentives can be created for multinational corporations to behave in environmentally responsible ways.
\end{abstract}

\section{INTRODUCTION}

no man is an island, entire of itself;

every man is a piece of the continent,

a part of the main

The ecological problems in the last century have brought home the idea that every action carried out by a person or a state will have a profound effect on another,

* L.L.M. Candidate, New York University Law School.

+ Associate Professor, National University of Singapore.

1. John Donne, Devotions upon Emergent Occasions 62 (Kessinger Publ. 2004) (1624).

Indiana Journal of Global Legal Studies Vol. 16\#1 (Winter 2009)

OIndiana University Maurer School of Law - Bloomington 
and it is this interconnectedness that has provided the impetus for the development of environmental law. The pollution by an upstream riparian state has a major effect on downstream riparian states, just as the burning of forests in one state has a major effect on its neighbors. Environmental law has developed through the background of this interconnectedness, and it is subsequently embedded in various legislative and policy frameworks that were developed in the past century.

Global environmental problems have been growing in magnitude. With global problems, we have come to believe, must come global solutions. From industrial accidents to climate change, this article will analyze how environmental law has responded to these challenges and has evolved in scale, reach, and complexity in the last century. In the early twentieth century, environmental law consisted mostly of domestic legislation. In the middle of the twentieth century, bilateral and regional legislation gained prominence. By the late twentieth century, the emphasis on global cooperation became the dominant trend. The evolution of environmental law in the past century has been linked to the growing acceptance of the notion of collective global responsibility. Recently, the focus of environmental law has shifted from the creation of global frameworks to deal with environmental problems to compliance with those frameworks. As a result, the primary actors in environmental law have shifted from the state and the global community to corporations. As a consequence, environmental policies must develop along legally holistic lines. By legally holistic I mean that environmental policy makers should consider all the laws and policy options available to incentivize or discourage a particular behavior and not limit their responses to the enactment of domestic or international environmental regulations or treaties.

\section{Historical Succession of Environmental Actors}

Before we explore the direction in which environmental policies should go, we have to examine from whence they came. The analysis of environmental law's evolution is vital in determining its future development. This Part will give a general overview of how environmental law has changed from the early twentieth century to today. This section will also explore the various trends in environmental law and determine possible approaches that environmental law should consider. We suggest the following diagram to illustrate the historical trends and future trajectory of environmental law. 


\section{A. Age of Legal Frameworks}

In the past century, the development of environment law has focused on the institutionalization of a legal framework to address environmental issues. As Figure 1 reflects, from the early twentieth century to the late twentieth century, the law, initially domestic but increasingly regional and international, placed obligations on the individual, then the corporation, then the state, and lastly the global community.

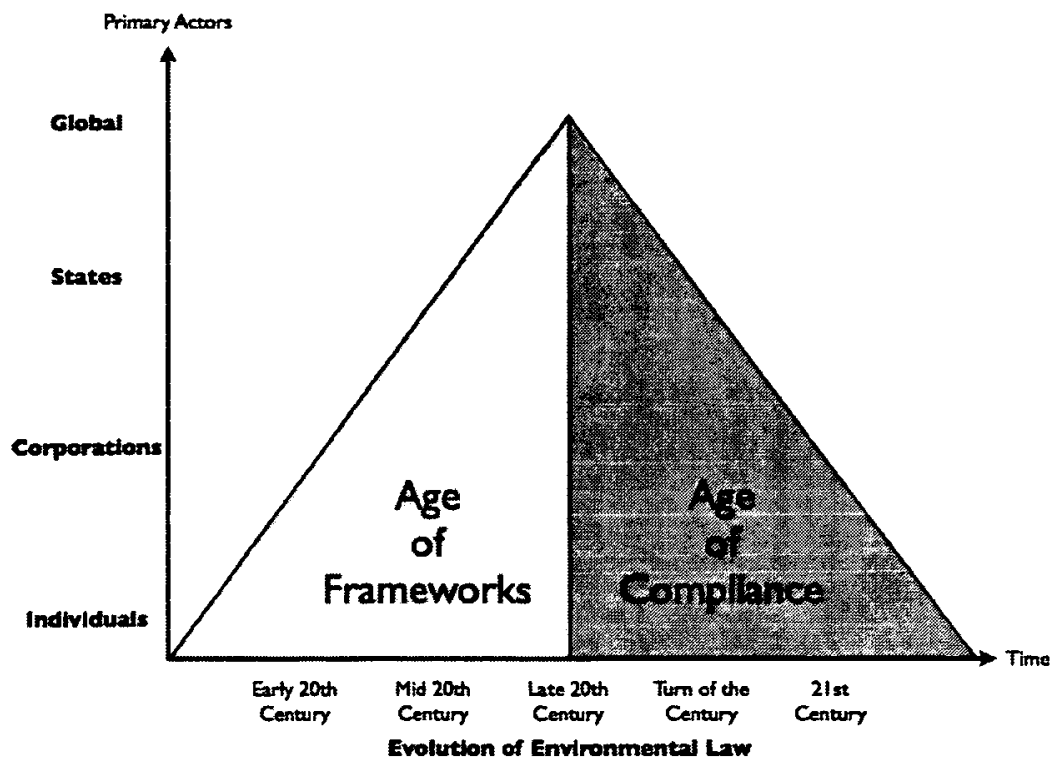

Figure 1: Evolution of Environmental Law and Change of Primary Actors

In the early twentieth century, states enacted domestic legislation to deal with environmental problems, realizing that individual actions required collective oversight at the state level. In the middle of the twentieth century, states had to regulate the actions of corporations as the strains of industrialization began to show on the environment. By the late twentieth century, the global community realized, given the global nature of environmental problems, that state action alone was inadequate and therefore instituted international regimes to mitigate those problems. 


\section{B. Age of Compliance ${ }^{2}$}

We have been seeing a reverse trend since the turn of the century as the international regime matures into the "age of compliance." Its focus is now not so much norm-setting as encouraging actor compliance. With the international regime and framework in place, we should see the primary actors of environmental law changing from the global community, to the state, to the corporation, and lastly to the individual. At the start of the twenty-first century, the global community will be pressuring states that are outliers to conform to norms set by the international regime. ${ }^{3}$ To conform to these norms, states will have to ensure that the behavior of their corporations and individual residents are kept within environmentally acceptable limits.

\section{Growing Focus on Corporations}

As domestic corporations and domiciled residents are already subject to domestic environmental legislation, in the twenty-first century multinational corporations (MNCs) will become the primary focus of environmental policies. If environmental law is to remain relevant and effective, the law has to take into account the vast scale and diversity of these MNCs. Because jurisdictional issues will limit the coercive power of any environmental law, the law must utilize a holistic approach under which other types of law, such as taxation law, trade law, and investment law, will be used to influence the way these MNCs behave. Before we examine how this is to be done, we must first learn from past efforts.

\section{Early Twentieth Century}

Arguably, environmental law in the early-to mid-twentieth century developed largely in a piecemeal way. Laws were enacted in a reactionary way and served only to address individual aspects of the environment in response to negative environmental events.

\section{A. Individuals}

In most states, environmental law began with domestic laws to protect endangered species, such as seals, whales, fish, and migratory birds. In the United

2. Edith Brown Weiss, to my knowledge, first used this phrase in her lecture, "Developments in the Evolution of International Environmental Law," given to the Singapore Attorney General Chambers on September 6, 2007.

3. Hilary French, Partnership for the Planet: An Environmental Agenda for the UNITED NATIONS 22-28 (1995). 
States, the Federal Migratory Bird Law, also known as the Weeks-McLean Law, was enacted in 1913. ${ }^{4}$ Subsequently, in 1966, the United States was the first country to pass an Endangered Species Act. ${ }^{5}$ The earliest domestic wildlife law in Australia was the Wildlife Conservation Act, 1950, which adopted protective measures for any indigenous Australian animal or periodic migrant. ${ }^{6}$ It defined animal as "any living thing that is not a human being." These laws marked the beginning of modern environmental law that served to protect the environment, with the principle of conservation in mind. The laws focused on restricting the behavior of individuals as the primary actors so as to protect non-humans, arguably for conservation purposes. Criminal sanctions against individual violators were enforced for breaches of such early environmental laws. ${ }^{8}$

Although conservationism has started to take shape, environmental law has been a very anthropocentric type of regime, focused on preserving the environment for mankind's future enjoyment or exploitation. This anthropocentric outlook has been fueled by a division between the physical and mental worlds, humanistic atomism, dichotomies between humanity and nature, considerations of how nature is valued, and a belief in the right to control and conquer nature. ${ }^{9}$ The philosophical root of this outlook is the belief that the environment provides many benefits to mankind. There are ecosystem benefits where plants and animals play an important role in maintaining the planet's ecological functions to ensure mankind's survival by providing basic necessities, such as food, potential medicinal products, and recreational and aestheric benefits. ${ }^{10}$ Environmental law

4. U.S. Fish \& Wildlife Serv., A Guide to the Laws and Treaties of the United States for Protecting Migratory Birds, http://www.fws.gov/migratorybirds/intrnltr/treatlaw.html (last visited Nov. 14, 2008).

5. Elaine L. Hughes et al., Environmental Law and Policy 466 (2d ed. 1998).

6. Wildlife Conservation Act, 1950 (W. Austl.), available at http://www.slp.wa.gov.au/pco/prod/ FileStore.nsf/Documents/MRDocument:5710P/\$FILE/WildifConsvnAct1950_07-b0-02 .pdf? OpenElement (last visited Nov. 18, 2008).

7. Id. $\S 6$.

8. See, e.g., id. § 26; Gerry Bates, Environmental Law in Australia 267-68 (3d ed. 1992); U.S. Fish \& Wildlife Serv., supra note 4.

9. Alexander Gillespie, International Environmental Law, Policy and Ethics 15 (1997). Gillespie also stated "[h]owever, this is not to claim that all environmental policy is exclusively anthropocentric. Within the last twenty years there has been a slow growth within environmental policy of the belief that Nature should be protected because of its own inherent value.... Nevertheless, despite this growing trend anthropocentricism currently remains central to contemporary environmental policy." Id.

10. Hughes ET AL., supra note 5, at 463-64. 
therefore has played an important role by addressing the potential" and utilitarian ${ }^{12}$ value of the environment to mankind.

The atomistic, and indeed parochial, nature of the early environmental laws can also be seen in the earliest non-conservation-oriented environmental laws that concerned themselves only with the domestic population at that point in time. The impetus for the creation of such laws was concern for public health and safety of a domestic population. In the United Kingdom, modern environmental laws were enacted to address mounting environmental concerns that had a direct effect on the domestic population's health. The Clean Air Act, 1956 was enacted to address widespread respiratory problems and deaths caused by air pollution during the great fog of London. ${ }^{13}$ Similarly, the Deposit of Poisonous Wastes Act, 1972 was enacted to address the harmful effects on humans caused by the discharge of poisonous industrial waste. ${ }^{14}$

\section{B. Corporations}

As industrialization progressed, the primary polluters (and therefore actors) shifted from individuals to corporations, and criminal sanctions in the form of fines were often enforced for corporate violation of pollution control legislation. ${ }^{15}$

Indeed, the development of modern environmental law has been linked to the economic development of society. As the amount of economic activity increases, there is a greater propensity to degrade the environment. Because the environment is the primary resource for most industrial activity, the increase in economic activities often results in greater natural resource consumption, environmental stress, and pollution.

In the United States, the development of industry and science tremendously improved the economic and social lives of the country's citizens, but this development came so fast that few predicted its environmental side effects-the harm caused to human health and the environment. ${ }^{16}$ As policymakers realized the

11. Laurence H. Tribe, Ways Not to Think About Plastic Trees: New Foundations for Environmental Law, 83 YALE L.J. 1325 (1975).

12. BATES, supra note 8 , at 256.

13. David Woolley, The History of Environmental Law, in ENVIRONMENTAL LAW 3, 38-39 (David Woolley et al. eds., 2000).

14. Id. at 41.

15. See Arnold W. Reitze, Jr., Air Pollution Control Law: Compliance and EnforceMENT 567-70 (2001).

16. Edward E. Shea, Environmental Law and Compliance Methods 631 (2002). 
level of environmental damage caused by economic development, laws had to be developed to regulate the conduct of industries. ${ }^{17}$

This was also the beginning of an understanding that individual actions required collective oversight at the state level. One of the most compelling justifications for state intervention has been that the state is responsible for addressing the externalities $^{18}$ of human actions. ${ }^{19}$

In the early twentieth century, states sought to mitigate the impact of individuals and domestic corporations by enacting environmental legislation that forced the primary actors to recognize externalities. By the early 1970 s, it was clear that the developments which began in the late stages of the twentieth century had gained momentum, resulting in the widespread recognition that the state had to take a more active role in the control of pollution and protection of its environment. ${ }^{20}$

\section{Mid-Twentieth Century - "No State is an Island"}

The Trail Smelter ${ }^{21}$ case was the first major international environmental law adjudication. Prior to this, apart from some riparian and shared ocean concerns, states mainly took the view that their use of natural resources and industrial activity within their borders were exercises of their sovereignty in which no other state should or could intervene. The arbitral tribunal in Trail Smelter enunciated the principle that states are responsible for environmental damage caused by activities conducted within their borders and that no state has the right to use or permit the use of its territory in such a manner as to cause injury to the territory of another or the properties or persons therein. ${ }^{22}$ This decision served as an important milestone, and customary international law has since developed along these enunciated lines of state responsibility.

States then began to realize that the actions of domestic industries could result in international responsibility for states. The Organization for Economic Co-

17. Id.

18. Tom Conway, Taking Stock of the Traditional Regulatory Approach, in GETTING IT GREEN: CASE Studies in Canadian Environmental Regulation 25, 28 (G. Bruce Doern ed., 1990) ("This means that the public cannot adjust for these costs and hazards in their calculations about wages, consumption, location of residence, and lifestyle. Moreover, most people are not able to adjust to these costs and hazards even when they possess information, because they lack the power and resources with which to respond. A government response in the common good is, therefore, necessary.").

19. Stuart Bell \& Donald McGillivray, Environmental Law 24 (2007).

20. Id.

21. Trail Smelter Case (United States v. Canada), 3 R.I.A.A. 1905 (Trail Smelter Arb. Trib. 1938).

22. Id. 
operation and Development defined "transfrontier pollution" as any intentional or unintentional pollution whose physical origin is subject to and situated wholly or in part within the area under the national jurisdiction of one state and which has effects in an area under the national jurisdiction of another state. ${ }^{23}$

The Chernobyl nuclear disaster in 1986, whose radiation fallout contaminated many European countries, graphically illustrated this interconnectedness. ${ }^{24}$ Indeed, some Welsh farmers are still under semi-permanent restrictions on lamb sales because of radioactive contamination from the Chernobyl radiation cloud. ${ }^{25}$ The transboundary nature and effect of environmental problems highlighted the need for transnational solutions.

By the 1960s, environmental issues began to take prominence and global awareness of the need for environmental protection was steadily rising. ${ }^{26}$ This was in no small part due to Rachel Carson and her famous book, Silent Spring. ${ }^{27}$ A round the same time, lakes of fire (oil pollution, acid rain, and ground water contamination) cases resulted in regional, transboundary rules to protect populations, particularly ocean and riparian populations. By 1969, the Cuyahoga River was so polluted with petrochemicals that it caught fire. ${ }^{28}$ This prompted the United States to enact the Clean Water Act of $1972,{ }^{29}$ which governed the elimination of toxic substances and water pollution.

By the early 1970 s, there was concern that air pollution could have detrimental effects on the environment and human infrastructure. High chimneystacks at power stations in the United States released sulphur dioxide emissions that caused acid rain in Canada. ${ }^{30}$ In response, Canada and the United States enacted legisla-

23. Organization for Economic Cooperation and Development, Council Recommendation on Implementing a Regime of Equal Right of Access and Non-Discrimination in Relation to Transfrontier Pollution, 16 I.L.M. 977, 979 (1977).

24. See generally John Greenwald et al., Soviet Union: More Fallout from Chernobyl, TiME, May 19, 1986 , at 44.

25. William Wilson, Making Environmental Laws Work-An anglo american ComPARISON 88 (1999).

26. Environmental consciousness and public awa reness have also been increasing at the beginning of the twenty-first century. On October 12, 2007, the Intergovernmental Panel on Climate Change and Al Gore were awarded the 2007 Nobel Peace Prize for "their efforts to build up and disseminate greater knowledge about man-made climate change, and to lay the foundations for the measures that are needed to counteract such change." Nobel Foundation, The Nobel Peace Prize 2007, http:// nobelprize.org/nobel_prizes/peace/laureates/2007/(last visited Oct. 5, 2008).

27. Rachel Carson, Silent SPRing (1962).

28. David D. Kemp, Exploring Environmental Issues: An INTEgrated Approach 290 (2004).

29. 33 U.S.C. $\S 1251(2000)$.

30. WILSON, supra note 25 , at 88 . 
tion to improve ambient air quality through the control of sulphur dioxide, nitrogen oxide, particulates, and carbon monoxide, thereby controlling acid rain in the region. ${ }^{31}$ In the context of oil spills, the Convention for the Prevention of Pollution of the Sea by $\mathrm{Oil}^{32}$ was concluded in 1954 to address the problem of oil discharges from ships and its effects on marine life.

A duty in international law began to emerge requiring states to cooperate with each other in combating environmental disasters and preventing ecological damage, and was subsequently reflected in the growing number of bilateral and multilateral agreements. This duty provided for emergency assistance and cooperation to mitigate damage..$^{33}$

\section{Late Twentieth Century}

\section{A. Global Community}

By the end of the twentieth century, states realized that environmental problems required a collective regional responsibility if they were to be mitigated. This was largely due to the nature of these problems. The depletion of the ozone layer in the polar regions and the growing concern about climate change were indicative of the magnitude of the environmental challenge. It became clear that alone, no country, however wealthy, could stabilize the climate within its borders or unilaterally protect the stratospheric ozone layer over its territory. If a single country continued to use large quantities of chlorofluorocarbons (CFCs), it would eventually deplete the stratospheric ozone layer over the entire earth. ${ }^{34}$

Developed countries recognized that acting alone, they would be unable to prevent climate change, conserve the planet's biological diversity, or otherwise resolve global environmental threats. ${ }^{35}$ The adoption of collective global responsibility shifted the focus of environmental law from domestic individuals and corporations to the international community at large. States became the primary actors and were required to negotiate bilateral and multilateral environmental agreements to solve

31. Edith Brown Weiss et al., International Environmental Law and Policy 578 (1998).

32. International Convention for the Prevention of Pollution of the Sea by Oil, Dec. 8, 1961, 12 U.S.T. 2989, 327 U.N.T.S. 3.

33. Edith Brown Weiss, Environmental Disasters in International Law, 1986 ANUARIO JURIDICO INTERAMERICANO 141 (1988), reprinted in BROWN WEISS ET AL., supra note 31, at 465, 471-72.

34. U.S. Envtl. Prot. Agency, The Twentieth Anniversary of the Montreal ProtocolA Landmark Environmental Treaty 1 (2007), http://www.epa.gov/Ozone/downloads/MP20_ Backgrounder.pdf.

35. David Hunter et al., International Environmental Law and Policy 190 (3d ed. 2007). 
the transboundary nature of environmental problems and use state-to-state pressure to address environmental issues. Global problems required global participation, and therefore necessitated a collective global responsibility for all states involved.

In 1972, the United Nations held its very first environmental conference, the United Nations Conference on the Human Environment, in Stockholm. The Conference was vital in providing the direction environmental law would take by the end of the twentieth century. The Stockholm Declaration and its Principles recognized the "need for a common outlook and for common principles to inspire and guide the peoples of the world in the preservation and enhancement of the human environment. ${ }^{36}$ Furthermore, the Stockholm Declaration affirmed the concept of state responsibility, ${ }^{37}$ thereby recognizing that every state has some level of responsibility in this global cooperative..$^{38}$

The international community recognized that global cooperation was going to be instrumental in the battle against environmental problems ${ }^{39}$ and that a global institution was required to coordinate the effort. Therefore, the Stockholm Conference institutionalized the United Nations Environment Programme (UNEP), the first global program to address environmental problems as a whole. The Stockholm Conference marked the beginning of a rapid increase in the number of international environmental agreements; 60 percent of all such agreements were made post-Stockholm. ${ }^{40}$ The Conference thus marked a historic milestone: the achievement of global consensus that a global cooperative was necessary to combat the global-transboundary nature and effect of environmental problems.

36. U.N. Conference on the Human Environment, Stockholm, Swed., June 5-16, 1972, Declaration of the United Nations Conference on the Human Environment, pmbl., U.N. Doc. A/CONF.48/14 (June 16, 1972).

37. Id. princ. 21 ("States have, in accordance with the Charter of the United Nations and the principles of international law, the sovereign right to exploit their own resources pursuant to their own environmental policies, and the responsibility to ensure that activities within their jurisdiction or control do not cause damage to the environment of other States or of areas beyond the limits of national jurisdiction.").

38. Id. I 7 ("Local and national governments will bear the greatest burden for large-scale environmental policy and action within their jurisdictions. International cooperation is also needed in order to raise resources to support the developing countries in carrying out their responsibilities in this field. A growing class of environmental problems, because they are regional or global in extent or because they affect the common international realm, will require extensive co-operation among nations and action by international organizations in the common interest.").

39. Id. princ. 24 ("International matters concerning the protection and improvement of the environment should be handled in a cooperative spirit by all countries, big and small, on an equal footing. Cooperation through multilateral or bilateral arrangements or other appropriate means is essential to effectively control, prevent, reduce and eliminate adverse environmental effects resulting from activities conducted in all spheres, in such a way that due account is taken of the sovereignty and interests of all States.").

40. Bell \& MCGillivRay, supra note 19, at 156; see also EdTTH Brown Weiss ET AL., INTERnATIONAL ENVIRONMENTAL LAW: BAsic INSTRUMENTS AND REFERENCES, at ix (1992) (stating that the volume contains about 932 different environmental instruments). 
By 1992, the global community was even more convinced of the severity of environmental problems plaguing the earth. The report of the World Commission on Environment and Development recognized that many environmental problems were global in their nature and effect. ${ }^{41}$ In 1992, the United Nations Conference on Environment and Development held in Rio de Janeiro was instrumental in formulating a regime to combat environmental problems. The focus of the conference was much more on global issues-principally the need to stabilize the climate and to protect the Earth's remaining plant and animal species.

The Rio Conference recognized that states had a sovereign right to pursue their own environmental and development polices. ${ }^{42}$ As opposed to the Stockholm Declaration, however, there was an addition of "development policies" in the Rio Declaration. In the past, economic development and environmental protection has been seen as polar opposites. By 1992, however, this view had changed. Environmental protection and economic development were no longer seen as mutually exclusive, but as goals that could be achieved and integrated together through the concept of "sustainable development." The Rio Conference thus moved international law into a new phase in which environmental and economic issues would be jointly discussed. ${ }^{43}$

Although environmental law, by its very nature, has always been global, it has only been recognized as such in the late twentieth century. Environmental problems facing states were, in reality, seldom confined to domestic populations. International law and its concept of sovereignty had placed boundaries between each state, demarcating states' areas of jurisdiction. However, environmental issues were never so limited. Environmental issues were always "globalized," as the Trail Smelter case and Chernobyl clearly illustrated. States are linked environmentally, and the transnational impact of an environmental issue can be as significant as its domestic impact. While environmental law increasingly recognized the global nature of environmental issues, other extrinsic factors, like the globalization of business and trade, contributed to the globalization of environmental law.

The 1990s saw significant increases in globalization. States, in an attempt to boost economic development, sought to liberalize trade. U.S. President Bill Clinton pushed for greater trade liberalization, which both directly and indirectly

41. See U.N. World Commission on Environment and Development, Our Common Future, U.N. Doc. A/42/427 (Mar. 20, 1987) [hereinafter Our Common Future].

42. U.N. Conference on Environment and Development, Rio de Janeiro, Braz., June 3-14, 1992, II 2, U.N. Doc. A/CONF.157/23 (June 13, 1992).

43. Edith Brown Weiss, International Environmental Law: Contemporary Issues and the Emergence of a New World Order, 81 Geo. L.J. 675, 679 (1993). 
contributed to the economic boom in the United States during the $1990 \mathrm{~s}^{44} \mathrm{In}$ addition, corporations went global. The late twentieth century saw a significant growth in the number of MNCs. Corporations took advantage of the lower cost of production ${ }^{45}$ in other states in order to increase their profit margins, thereby expanding their business operations to multiple states. Corporations also expanded their markets beyond the initial domestic customer base that they had in their home countries. The globalization of business and trade therefore intensified, inevitably placing pressure on the environment. ${ }^{46}$

In 2002, the World Summit on Sustainable Development was held in Johannesburg. It produced the Johannesburg Declaration, ${ }^{47}$ which was a political state-

44. U.S. Dep't OF State, An OUtLine OF THE U.S. ECONOMY (2001), http://usinfo.state.gov/products/pubs/oecon/chap3.htm.

45. Lyuba Zarsky \& Simon S.C. Tay, Civil Society and the Future of Environmental Governance in Asia, in Asia's Clean Revolution: Industry, Growth and the Environment 128, 140 (David P. Angel \& Michael T. Rock eds., 2000) ("Beyond Asia, environmental NGOs, labour groups and other advocacy groups throughout the world have raised concerns about the adverse costs of globalisation. In the West, many focus on the outflow of jobs from the more developed and more expensive economies to cheaper centres of production in Asia and elsewhere.").

46. See James Gustave Speth, Red Sky at Morning: America and the Crisis of the Global ENVIRONMENT 145 (2004). On one hand,

economic globalization leads to (1) an expansion of environmentally destructive growth, (2) a decrease in the ability of national governments to regulate and otherwise cope with environmental challenges, (3) an increase in corporate power and reach, (4) the stimulation of particular sectors like transportation and energy that have largely negative environmental side effect, (5) the increased likelihood of economic crisis, (6) the commodification of resources such as water and the decline of traditional local controls on resource use, (7) the spatial separation of action and impact from responsibility, (8) the further ascendancy of the growth imperative, and (9) the rapid spread of invasive species and the resulting biological homogenization.

Id.

On the other hand,globalization may help environmental quality. (1) Global corporations can help spread the most advanced environmental management technology and techniques; (2) the strengthening of capacities in government to manage economic affairs can have spillover effects, strengthening environmental management; (3) globalization can lead to increased incomes, which in turn can lead to governmental revenues for environmental and social programs and to increase public demand for environmental amenity; (4) and increasing international trade in such resources as timber could lead to higher prices, more secure property rights, and larger investments in sustaining forest resources.

Id.

47. World Summit on Sustainable Development, Report of the World Summit on Sustainable Development, Johannesburg, S. Afr., Aug. 26-Sept. 4, 2002, at 1-5, f1 1-37, U.N. Doc. A/CONF.199/20 
ment of a continued commitment to sustainable development. The Johannesburg Summit also recognized that globalization and its effects have increased the scale and diversity of environmental issues and that environmental law would need to take note of these changes in order to remain effective.

The globalization of business and trade has intensified the need to regulate the behavior of MNCs. The scale and reach of these transnational businesses now make them significant actors in the environmental arena. ${ }^{48}$ Indeed, the Johannesburg Plan of Implementation devotes an entire chapter to "[g]lobalization and sustainable development." ${ }^{\text {"99 }}$ The main actors in globalization have always been the MNCs, and the Johannesburg Plan recognized this by encouraging nations to "[a]ctively promote corporate responsibility and accountability."so

\section{Multinational Corporations as Environmental Actors in the Early Twenty-First Century}

Throughout the evolution of environmental law up to this point, the international community has attempted to find international norms capable of solving these global environmental problems. In the "age of frameworks," international regimes (whether sufficiently effective or not) were institutionalized to address the global nature of environmental problems. In the twenty-first century, the focus will be the actual implementation of these international regimes as the evolution of environmental law enters the "age of compliance." For environmental law to remain relevant and effective, it must target the primary actor in globalization-the multinational corporation.

\section{A. Compliance Challenges}

The significance of engaging these corporations cannot be underestimated. Arguably, MNCs can assert more influence on an environmental issue than can a treaty. ${ }^{51}$ States are more likely to comply with the demands of corporations because corporations are necessary components to the economic development of the

[hereinafter Johannesburg Report].

48. FreNCH, supra note 3, at 43.

49. Johannesburg Report, supra note 47, at pp. 37-39, II 47-52.

50. Id. at p. 38, I 49.

51. See Simon S.C. Tay, South East Asian Fires: The Challenge to International Law and Sustainable Development, 11 Geo. INT'L ENVTL. L. Rev. 241, 297 (1999) ("Private individuals and organizations can help foster and enforce compliance within the relevant industries in Indonesia."). 
states. Similarly, MNCs can also make environmentally friendly processes mandatory in their overseas production lines, thereby creating a beneficial global effect on environmental issues.

Sadly, the reverse is also true. If these corporations adopt environmentally unfriendly practices, global harm will occur. Furthermore, if developing countries are dependent on MNCs for their economic development, the states are likely to be reluctant to apply pressure on the corporations to improve their practices.

Hence, if extrinsic factors were to influence these MNCs to incorporate sustainable development into their practices, this could have a greater effect than merely applying state-to-state pressure. Furthermore, engagement of the MNCs with the project of environmental protection could provide a possible solution to the problem that some developing countries face. Many developing countries are unable to comply with some treaty requirements, not because of a lack of political will but because of the shortages of financial and technological resources. ${ }^{52}$

The environmental law of the twenty-first century must adopt a legally holistic approach to influence MNCs. Environmental law and the global agreements combating environmental problems are inadequate and ineffective if they operate in isolation. Today, there are international agreements to control pollution in all aspects of the environment, to "conserve habitats, protect global commons, such as the high-level ozone layer, and protect resources located within countries that are of concern to the international community." ${ }^{\prime 3}$ Similarly, the "duties of the parties to these agreements have also become more comprehensive: from undertaking research and monitoring to preventing pollution and reducing certain pollutants to specified levels." ${ }^{54}$ The development of environmental law has been geared toward the creation of a global framework to address environmental problems.

\section{B. The Unique Role of MNCs in Achieving Compliance}

However, compliance with this framework alone is insufficient and ineffective in solving the environmental problems it sought to curb. The problem lies with the globalized and diverse nature and effects of the MNCs. First, MNCs, as

52. FRENCH, supra note 3, at 24; see also Marc A. Levy et al., Improving the Effectiveness of International Environmental Institutions, in INSTITUTIONS FOR THE EARTH 397, 404-05 (Peter M. Haas et al. eds., 1993) ("Leaders of weakly institutionalized states may genuinely want to conform to international norms and principles and comply with regime rules, but may lack the political legitimacy, or the loyalty of competent and honest bureaucracies, necessary to develop and implement domestic initiatives.").

53. Weiss, supra note 43 , at 679 .

54. Id. at 680 . 
their name suggests, have business operations that span the globe. They are not confined to the sovereign boundaries of any state, and therefore no particular state has the jurisdiction to regulate completely the business operations of a particular MNC. ${ }^{55}$ Second, the role of MNCs is no longer confined to specific products or services. Through the globalization of business and trade, corporations have expanded their operations. The nature of MNCs necessitates the development of environmental law in a legally holistic manner in order to bring sustainable development to bear as an influence on their business decisions.

Environmental law will have to utilize other types of law like tax law, investment law, and trade law in order to become an effective international regime to combat environmental problems. Without the utilization of other types of law to influence these diverse MNCs, the aim of sustainable development will not be met.

Before we deal with the analysis of the legally holistic approach, it should be pointed out that the objective of the approach is to develop an environmental policy that not only seeks to regulate the behavior of corporations but also engages these MNCs in order to have a long-term international regime of sustainable development and environmental protection. The regime must encourage these corporations to seek change themselves. Strict compliance measures alone will only serve to cultivate an attitude of minimum effort, which is just enough to avoid any limited legal sanctions. ${ }^{56}$ In contrast, if we can engage corporations to play a more proactive role, environmental law will be more efficient and effective. Companies will not only satisfy requirements to avoid state sanctions but will also do more because it is seen to be in their corporate interest to solve environmental problems.

Indeed, MNCs can be, and have been in some cases, a positive force for change in developing countries by transferring environmental technology, enforcing environmental standards at their factories, and sharing best practices with the local workforce. In this respect, MNCs are far better at influencing change at the local level.57

While pressure from developed states has been met with resistance from de-

55. Nitin Desai, The Road to Johannesburg, 15 Geo. INT'L EnvTL. L. Rev. 809, $812-20$ (2003) ("A class of very powerful actors who cannot be completely within the jurisdiction of one government, who are not under the influence of one government because their operations are spread across many different jurisdictions. And this is again a new feature: a class of very powerful actors who operate across jurisdictions and were not necessarily looking at issues purely from a national perspective.").

56. Id. at 817 ("We cannot get this type of engagement by the corporate sector by ordering them around.").

57. Zarsky and Tay, supra note 45, at 151 ("TNCs from OECD countries utilise and transfer clean technology and have better management systems than local firms in developing and transition economies. Increasing FDI will thus help environmental standards and performance to converge towards OECD levels."). 
veloping countries, who are suspicious of hidden protectionist agendas, MNCs are largely seen as neutral or even positive influences by many developing countries, as evidenced by the number of bilateral investment treaties many of these developing countries have signed, as well as the efforts many of them of them have made to woo these MNCs. Most developing countries do not see the MNCs generally as threats to their sovereignty, but rather as vital components to their development. ${ }^{58}$ If developing countries were not cooperating with other states on the basis of economic development, they would be more likely to cooperate with corporations because corporations are the ones who will boost their economic development through foreign direct investment. ${ }^{59}$ Developing countries are therefore dependent on these MNCs and are generally more receptive to their proposals. MNCs could thus provide pivotal environmental advice and, more importantly, impose their own environmental standards on their subcontractors. All of this could also gradually diffuse into the local industries which have grown up around the foreign direct investment brought in by the MNCs and whose environmental standards have traditionally been much lower than those of most MNCs.

\section{Maximizing the Contribution of MNCs Through the Levers of "Pain, Gain, and Shame"}

In order for environmental law and lawyers to engage corporations, the analysis of the legally holistic approach must incorporate a business perspective. If we accept an anthropocentric basis of environmental law (as many environmental scholars do), it would mean that the very basis of environmental law is some form of self-interest. ${ }^{60}$ Therefore, the engagement of corporations by way of their selfinterest should not necessarily be seen as a Faustian pact.

It is proposed that a Performance Venn formula can be used to appeal to a particular corporation's self-interest.

In order to engage corporations, a legally holistic approach must incorporate the potential effects that these three influences have on the performance of corpo-

58. Daniel Chudnovsky \& Andrés Lopéz, UnCTAD-UndP Global Programme on Globalization, Liberalization and Sustainable Human Development, Globalization and Developing Countries: Foreign Direct Investment and Growth and Sustainable Human DEVELOPMENT 1 (1999), http://www.fund-cenit.org.ar/eng/Descargas/globalization.pdf.

59. See Brett Pomainville, The Road to Johannesburg, 15 Geo. INT'L ENvTL. L. REv. 809, 822 (2003) (noting that "nine out of ten dollars that go to developing countries actually come from private sources and not from government sources").

60. GILLESPIE, supra note 9 , at 19. 


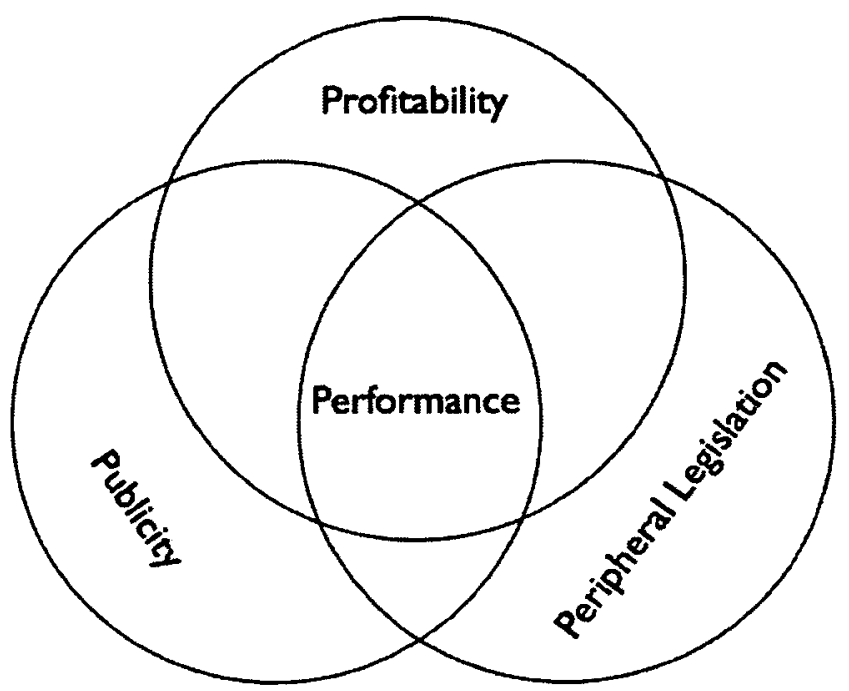

Figure 2: Performance Venn Diagram

rations. The overall performance of corporations is dependent on three influences: the profitability of the corporation, the positive or negative publicity resulting from the corporation's behavior, and the peripheral legislation regulating the corporation. In short, by incorporating the tools of "pain, gain, or shame" into environmental policies, the behavior of a corporation may be better influenced..$^{61}$

In some ways this echoes the terminology used by Brown Weiss and Jacobson regarding strategies for encouraging state compliance with environmental law. ${ }^{62}$ Using a matrix of "intention" and "capacity," they suggest that a policy toolkit of sanctions, incentives, and "sunshine" can be part of a strategy to strengthen state compliance. ${ }^{63}$ Their empirical study showed that where intention and capacity of states to comply were strong, sunshine was the most appropriate tool. ${ }^{64}$ However, where capacity was weaker, incentives were necessary to increase the capacity. Conversely, where intention was weaker, sanctions and sunshine were necessary to encourage compliance..$^{65}$

It is not within the scope of this paper to provide an empirical or even a compre-

61. See Zarsky \& Tay, supra note 45, at 151 (explaining that "the fact that TNCs feel themselves to be under public scrutiny may well help to improve their environmental and social performance").

62. See Edith Brown Weiss \& Harold K. Jacobson, Engaging Countries: Strengthening COMPLIANCE WITH INTERNATIONAL ENVIRONMENTAL ACCORdS 511-54 (1998).

63. Id. at 550 .

64. Id.

65. Id. 
hensive list of the various policy tools available to encourage compliance by MNCs. Instead, this paper will content itself with providing only a brief survey of certain tools which have worked in the past and explaining how they have worked.

\section{Pain}

Trade measures were commonly used in the late twentieth century as a way of addressing environmental concerns. Trade restrictions have been enacted and used to protect the environment of importing states, exporting states, and the global commons. ${ }^{66}$ These trade measures are arguably effective ${ }^{67}$ in the regime of environmental protection if they have a direct impact on the vested economic interests of the violating corporations.

The Tuna cases ${ }^{68}$ involved import restrictions imposed by the United States on tuna because of the concern about the incidental effect on dolphin populations of certain tuna-fishing methods. Although the United States was found to be in breach of its WTO obligations, the overall effect of this dispute eventually led to the signing of an international agreement to phase out dolphin-unfriendly fishing methods. ${ }^{69}$

Later, the Shrimp case ${ }^{70}$ arose out of the U.S. requirement that states exporting shrimp to the United States show that their harvesting methods were consistent with U.S. standards. This requirement imposed "a single, rigid and unbending requirement" of "essentially the same" policies and enforcement practices as those applied to and enforced upon domestic shrimp trawlers in the United States, and it was eventually held that there were no good reasons for other equivalent standards not to be recognized. ${ }^{71}$

While there is some concern that such environmental trade restrictions could disguise trade protectionism, the jurisprudence of the WTO has now probably

66. BeLl \& MCGILlivray, supra note 19, at 168.

67. See FrENCH, supra note 3, at 23 (describing the trade restrictions in the Montreal Protocol as critical to the success of the treaty).

68. Report of the Panel, United States-Restrictions on the Imports of Tuna, L/5198 (Feb. 22, 1982), GATT B.I.S.D. (29th Supp.); Panel Report, United States-Restrictions on the Imports of Tuna, WT/ DS29/R (June 16, 1994) (unadopted).

69. See Agreement for the Reduction of Dolphin Mortality in the Eastern Pacific Ocean, June 1992, 33 I.L.M.936; Agreement on the International Dolphin Conservation Program, May 21, 1998, 37. I.L.M. 1246, available at http://www.iattc.org/PDFFiles2/AIDCP\%20_amended\%20Oct\%20 2003_\%20REV.pdf.

70. Appellate Body Report, United States-Import Prohibition of Certain Shrimp and Shrimp Products, WT/DS58/AB/R (Oct. 12, 1998) (adopted Nov. 6, 1998) [hereinafter Shrimp I].

71. Appellate Body Report, United States-Import Prohibition of Certain Shrimp and Shrimp Products Recourse to Article 21.5 DSU by Malaysia, WT/DS58/AB/RW, II 177 (Oct. 22, 2001) [hereinafter Shrimp II]. 
provided enough clarity regarding the WTO rules to prevent blatant protectionism. As such, trade restrictions could be one part of a legally holistic approach encouraging environmentally positive behavior by MNCs.

Environmental protection has also been aided by the increasing use of environmental impact assessments (EIAs). In the 1970s, the World Bank had been criticized for providing support for some of the most environmentally damaging projects in developing countries. In response to this, the World Bank adopted an environmental strategy that was to be integrated into its policies. Countries that apply for loans are responsible for preparing environmental assessments (EAs) for each project. ${ }^{72}$

These EAs are extremely useful in promoting environmental practices in these countries. Environmentally friendly practices can be mandated as conditions in the loans, as can the requirement that certain environmental steps be taken before the loans become effective. Countries will therefore take more proactive measures in environmental policies so that they can take advantage of financing instruments by the World Bank. ${ }^{73}$ Because of their obligations under these financing agreements, states will be more inclined to regulate the behavior of MNCs involved in projects that are funded by the World Bank.

Similarly, in the arena of free trade agreements and bilateral investment treaties, states have been instrumental in regulating environmental practices of corporations. In the North American Free Trade Agreement (NAFTA), ${ }^{74}$ several steps, including the side treaty to NAFTA-the North American Agreement on Environmental Cooperation (NAAEC) ${ }^{75}$ - have been taken to advance environmentally sensitive investment and to discourage relaxation of environmental standards

72. Under World Bank Operational Policies 4.01, the borrowing country is responsible for preparing environmental assessment (EAs) for the project, including (1) potential environmental consequences of projects identified early in project cycle, (2) projects categorized according to the significance of their environmental and certain social impacts, (3) EAs and mitigation plans required for projects with significant environmental impacts or involuntary resettlement, (4) EAs should include analysis of alternative designs and sites, or consideration of "no option," (5) requires meaningful consultation and information disclosure before Board approval. World Bank, World Bank Operational Manual, OP 4.01 If 1-5, http://wbln0018.worldbank.org/Institutional/Manuals/OpManual.nsf/tocall/ 9367A2A9D9 DAEED38525672C007D0972? Open Document (last visited Sept. 2, 2008).

73. Some commentators observe that the subsequent national policies adopted by the borrowing state are just paying "lip service" to these conditions, and may not be ultimately enforced. Fola S. Ebisemijuela, Making it Work in Developing Countries, in 1 CAPACITY BUILDING FOR ENVIRONMENTAL LaW in the Asian and Pacific Region 571, 573 (Donna G. Craig et al. eds., 2002).

74. North American Free Trade Agreement, U.S.-Can.-Mex., Dec. 17, 1992, 32 I.L.M. 605.

75. North American Agreement on Environmental Cooperation, U.S.-Can.-Mex., Sept. 14, 1993, 32 I.L.M. 1480. 
as a means of attracting investment. ${ }^{76}$ This goal has since been echoed in many other regional trade agreements. ${ }^{77}$

There has long been a concern that the need to attract MNCs, and the foreign direct investment they bring in, could potentially lead to a race to the bottom. ${ }^{78}$ There was a belief that MNCs would seek to use environmentally damaging but profit maximizing processes in developing countries that were prohibited from use in their home countries. ${ }^{79}$ Fortunately, this has not completely come to pass. Concerns among the local populations of potential host states have led many developing countries to adopt EIA legislation and other forms of environmental regulation to limit this.

The use of EIAs will play a major role in influencing the environmental practices of corporations. In order to secure investments in foreign states, corporations will have to assess the impact that their investment and business operations will have on the environment. If these corporations do not conduct EIAs, quite apart from the potential legal consequences (the "pain") there also could be a negative effect on their public reputation. Indeed, the naming of these corporations in a lawsuit or in the press will serve to "shame" these corporations, which could also ultimately have an effect on their financial bottom line. Therefore, in addition to adopting environmentally friendly practices to satisfy the EIAs ${ }^{80}$ and ultimately state obligations in their

76. Raymond B. Ludwiszewski \& Peter E. Seley, "Green" Language in the NAFTA: Reconciling Free Trade and Environmental Protection, in NAFTA AND THE ENVIRONMENT 1, 11-13 (Seymour J. Rubin \& Dean C. Alexander eds., 1996).

77. See Organization for Economic Cooperation and Development, Recent Developments in RTAs/FTAs Containing Environmental Provisions, http://www.oecd.org/dataoecd/37/48/41306548 .pdf (last visited November 14, 2008).

78. See Zarsky \& Tay, supra note 45, at 134 ("The political will to raise environmental performance may be even weaker now, given increased hunger for FDI and investor concerns about the competitiveness and stability of the region."); $i d$. at 140 ("Competition for foreign investment and trade can act as a force of gravity dragging down environmental commitments.").

79. Gunther Handl \& Robert E. Lutz, Transferring Hazardous Technologies and Substances: The International Legal Challenge (1989); see also French, supra note 3, at 43; Andrew Harding, Practical Human Rights, NGOs and the Environment in Malaysia, in Human Rights Approaches to Environmental Protection 227, 238 (Alan E. Boyle \& Michael R. Anderson eds., 1996) (discussing the Asian Rare Earth case where the factory "was prevented from operating in Japan because of strict environmental laws"); Sanjeev Khagram, Toward Democratic Governance for Sustainable Development: Transnational Civil Society Organizing Around Big Dams, in THE THIRD Force : The Rise of Transnational Civil Society 83,90 (Ann M. Florini ed., 2000) (In the context of dam projects, "big dam proponents moved their activities to countries where demand for these projects was still high, international funding available, criticism of big dam building less organized, and democratic and environmental norms less institutionalized.").

80. Philippe Sands, Principles of International Environmental Law 821-22 (2d ed. 2003). 
financing agreements, MNCs will want to develop their processes in an environmentally friendly way in order to increase their market share and profitability.

It is interesting to note that a series of investment arbitration cases have directly or indirectly upheld the rights of host states to cancel foreign investments, on the basis of a legitimate public purpose, if such investments lead to environmental degradation. ${ }^{81}$ While some concerns were raised by the Metalclad case, ${ }^{82}$ a restatement of the law on expropriation in the Methanex case ${ }^{83}$ has suggested a more environmentally sensitive direction for the rules on foreign direct investment. In the Methanex case, a Canadian company was unsuccessful in its claim against the United States that a California ban on a chemical that was the company's main product and a potentially toxic contaminant amounted to a regulatory taking. The arbitration tribunal held that as long as a regulatory measure was for a public purpose, was nondiscriminatory, and was enacted in accordance with due process, it is not an expropriation and need not be compensated unless the government had given specific commitments to refrain from such regulation. ${ }^{84}$

\section{Gain}

One other factor influencing MNC behavior has been the development of the "polluter pays" principle in environmental policies. Pollution and waste taxes have been used to implement environmental protection by transferring the cost of environmental damage to the party causing the damage. Ideally, environmental taxes should be variable, as opposed to a fixed baseline tax, in order to encourage sustainable development. If these taxes are fixed baseline taxes, corporations will not find a need to improve on their processes because these taxes will have to be paid at the start. A variable tax can be in the form of an energy tax or an emissions tax. The tax should have some relation to the production levels of the corporation.

The imposition of variable taxes will encourage corporations to adopt a level of sustainable development. The profitability of the corporation will be affected

81. One of the earliest of these cases was International Bank of Washington v. Overseas Private Investment Corp., 11 I.L.M. 1216 (1972) (Baker, Danvazansky, Moore, Arbs.).

82. Metalclad Corp. v. United Mexican States, Case No. ARB(AF)/98/2 (Int'l Ctr. for Settlement of Inv. Disputes 2000), reprinted in 15 ICSID Rev. ForEIGN INv. L.J. 214 (2000).

83. Methanex Corp. v. United States, 44 I.L.M. 1345 (NAFTA Chapter Eleven Arbitral Trib. 2005), available at http://www.state.gov/documents/organization/51052.pdf.

84. Id. pt. IV, $\S 3(7)$ (" $[\mathrm{A}] \mathrm{s}$ a matter of general international law, a non-discriminatory regulation for a public purpose, which is enacted in accordance with due process and, which affects, inter alios, a foreign investor or investment is not deemed expropriatory and compensable unless specific commitments had been given by the regulating government to the then putative foreign investor contemplating investment that the government would refrain from such regulation."). 
by the total amount of taxes that it must pay. The imposition of a carbon or energy tax will have a direct effect on the corporation's cost of production, thereby implicating its self-interest. These corporations will be more motivated to adopt methods that will decrease their amount of emissions or decrease the amount of energy they need to consume so that less tax will eventually have to be paid. ${ }^{85}$

Similarly, taxes may indirectly affect the public images of these corporations. Because the cost of production is at stake, investors will increase their focus on the business operations of the corporations. If corporations are consistently paying high taxes due to environmentally unfriendly processes, investors may be discouraged from investing in those companies, as this will have a direct effect on the profitability of the company and hence the return on investment. Similarly, shareholders of these corporations will take greater notice of the production processes, as the linked taxes will have an impact on the shareholders' investment. When seen in this perspective, corporations will be more proactive in adopting environmentally friendly procedures in order to boost the performance of their businesses. ${ }^{86}$

Indeed, whatever one thinks of the efficacy of the Kyoto Protocol ${ }^{87}$ and the emissions trading regimes that have sprung up in the wake of its "cap and trade" system, it is clear that they have created a gain for many MNCs. Whether or not some gaming of the emissions trading exists, this is a critique of the implementation of the system rather than of its fundamental ideology. Regardless, the establishment of a perspective that is directly related to profits will encourage environmental concerns to be more firmly established in MNC boardrooms.

However, the "gain" part of the equation need not arise only from domestic, or even international, regulations. Esty and Winston have documented many situations in which it has been costly for companies not to have an environmental strategy, and profitable for companies who have used such an environmental strategy to gain an advantage. ${ }^{88}$ 'They note that 'the 'gold' that smart companies mine from being green includes higher revenues, lower operational costs, and even lower lending rates from banks that see reduced risk in companies with carefully constructed environmental management systems." ${ }^{99}$ They highlight how

85. See Daniel C. Esty \& Andrew S. Winston, Green to Gold: How Smart Companies Use Environmental Strategy to Innovate, Create Value and Bulld Competitive Advantage (2006).

86. Id.

87. Kyoto Protocol to the United Nations Framework Convention on Climate Change, Dec. 10 , 1997, 37 I.L.M. 22.

88. See ESTY \& WINSTON, supra note 85, at 2.

89. Id. at 11 . 
"BP's chief executive, Lord John Browne, committed the company to reducing its emissions of the greenhouse gases that contribute to global warming, especially carbon dioxide" and after three years, BP discovered numerous ways to cut emissions, improve efficiency, and save money. ${ }^{90}$ The initial process changes cost $\mathrm{BP}$ about $\$ 20$ million but saved the company an impressive $\$ 650$ million over those first few years. As of 2006 , the savings topped $\$ 1.5$ billion." ${ }^{, 91}$

\section{Shame}

Esty and Winston have noted that MNCs "also reap soft benefits, from a more innovative culture to enhanced intangible value, credibility, and brand trust." ${ }^{\text {"92 }}$ They highlight how General Electric (GE) CEO Jeff Immelt announced a new initiative, "ecomagination," committing the huge MNC to double its investment in environmental products so as to position GE as the cure for many of the world's environmental ills. ${ }^{93}$ Similarly, they point to Toyota's green focus and the remarkable success of the Prius and the environmental premium it commands as a green statement of how such intangible values can be converted to clear profits. ${ }^{94}$

Conversely, they also point out that most MNCs ultimately should be aware that if a corporation oversteps the restrictions of its operating license, there are severe consequences. ${ }^{95}$ The Union Carbide disaster in Bhopal, India, and the Exxon Valdez incident are just two of the examples they raise. ${ }^{96}$ More recently, the corporate losses arising from the use of lead paint in Chinese toys has further served to underline the cost of shame.97

\section{Other Policy Challenges}

Environmental law must therefore utilize other types of law in order to achieve its goal of sustainable development. However, the legally holistic approach will also bring about certain policy challenges that environmental law must address: the intergenerational conflict, the developing-developed conflict, protectionism, rent seekers, and "similar in effectiveness" standards.

90. Id. at 2 .

91. Id.

92. Id.

93. Id. at 7.

94. Id. at 10 .

95. Id. at 12 .

96. Id. at 12-13.

97. Eric S. Lipton \& David Barboza, As More Toys are Recalled, the Trail Ends in China, N.Y. Times, June 19, 2007, at Al. 
When formulating the extent of measures under the legally holistic approach, we must consider issues stemming from the intergenerational conflict. The objective of the legally holistic approach is to influence states and corporations to adopt sustainable development. However, one problem facing environmental lawyers is determining how many measures environmental law must introduce in order to strike a fair balance between the current generation's needs and the needs of future generations.

Quite apart from the intractable definitional problem of the term "developing country," the dispute between the developed and developing countries has mainly centered on the level of environmental protection required by each of them. Developing countries have stressed that they have the sovereign right to develop and therefore should not be "held back" by the proposed environmental protection methods. The developing countries also maintain that developed countries must take primary responsibility in tackling these environmental problems because they were the primary contributors to the current environmental problems during their industrialization. ${ }^{98}$ Since developed countries had the opportunity to develop, developing countries feel that their right to develop should not be hindered.

Conversely, developed countries are reluctant to increase their environmental protection measures because of their perception that developing countries are not doing enough. In 1997, the U.S. Senate passed the Byrd-Hagel Resolution, ${ }^{99}$ declaring that the United States would not be a signatory to the Kyoto Protocol unless it also included mandated scheduled commitments by developing countries. The rationale for this reaction is not entirely unjustified. If developing countries are not engaged, they will be able to gain the "lost" market share resulting from the restrictions that developed countries are imposing on themselves. Unfortunately, this situation is a vicious cycle. Developing countries will not do more because they see that developed countries are not doing enough. Similarly, developed countries will not do more if developing countries are not participating in these environmental measures.

The use of environmental protection measures like trade restrictions can also result in the criticism that they amount to protectionist measures by developed countries. In the area of ecolabelling, "some [developing countries] argue that to the extent ecolabels include information relating to [processing and production] methods (PPMs), they constitute an unjustified and illegal intrusion into the sov-

98. Anita M. Halvorssen, Common, but Differentiated Commitments in the Future of Climate Change Regime-Amending the Kyoto Protocol to Include Annex $C$ and the Annex C Mitigation Fund, 18 Colo. J. INT'L ENVTL. L. \& POL'Y 247, 254 (2007) (“[I]t is not equitable for developing countries to equally share the burden of controlling [greenhouse gas] emissions when, until recently, developed countries have done most of the polluting.").

99. S. Res. 98,105 th Cong. (July 25, 1997). 
ereignty of exporting countries." ${ }^{100}$ PPM ecolabels are a concern because they provide an avenue for a developed country to take protectionist and restrictive trade measures under the guise of an environmental measure. ${ }^{101}$

While there has been much criticism of the vagaries of the ecolabelling process, such criticism is again largely a critique of the implementation of the method rather than the need for certain standards. In the Shrimp II case, ${ }^{102}$ arising from the Shrimp I case, the Appellate Body upheld the modified "comparable in effectiveness" standard used by the United States to determine if the production process for the catching of shrimp was acceptable. Indeed, if environmental law were to utilize environmental standards as a tool in the overall environmental protection regime, there will be a need to harmonize these standards. ${ }^{103}$ The main problem is that there are too many differing environmental standards. The harmonization of these standards into a single, applicable international standard would be a difficult task, and an equivalent standard modality may eventually be a possible solution.

While all of the issues just discussed are compelling issues that states will eventually have to resolve, a focus on MNCs as agents for positive environmental change avoids a significant number of the public law, international law, and standard harmonization issues because MNCs will not necessarily need to resolve them. MNCs are not locked into a developed or developing debate, nor do they have to balance the generational conflict concerns. MNCs are also able to set their own standards.

Corporations today are very conscious of environmental concerns, partly due to the many protests conducted by groups and, even more importantly, because consumers and investors have increasingly been putting their money where their mouths are and paying a premium for environmentally responsible products and shares of environmentally friendly corporations. ${ }^{104}$ Corporations have also seen more limits placed on their

100. Peter L. Lallas \& Andreas R. Zeigler, International Economics, Trade and the Environment, in InTERnational ENvironmental LaW and Policy supra note 31, at 1075.

101. See FRENCH, supra note 3, at 44 ("[M]any developing countries are concerned that a proliferation of eco-labelling schemes in industrial countries will keep their products out of northern markets. Many trade officials also worry that environmental laws can serve as cover for what are really just commercial barriers."); see also Zarsky \& Tay, supra note 45, at 150 ("For Asian-based manufacturers, the concerns are quite the opposite. There is suspicion that ISO standards are set by industrialised countries to provide a non-tariff barrier to trade, using a green excuse for protectionist intention.").

102. Shrimp II, supra note 71, II 177.

103. Zarsky \& Tay, supra note 45, at 147 ("As a whole, business tends to prefer stability and predictability in policy-making, including on the environment. Transnational companies find it useful for standards to be similar in different countries in which they operate and often claim to adopt uniform internal company-wide standards.").

104. See ESTY \& WINSTON, supra note 85. 
methods of production as the creation, monitoring, and enforcement of national and international environmental standards have grown more sophisticated.

As a result, MNCs have gone increasingly into the "greendustry" sector. Businesses like BP and General Electric have leveraged the compliance regime of environmental protection and taken advantage of business opportunities like alternative energy and the clean development mechanism. Nonetheless, the reality is that these greendustry corporations, though "green," remain corporations. Their main objective, like all corporations, is to make profit. Their inherent motives must be questioned: are they here to save the planet, or are they here to save the planet because there is money to be made in saving the planet? Is all this greendustry really just "greenwash" motivated purely by profits?

Not completely. In addition to these external factors, internally, corporate executives have become more educated about sustainable development and the environmental interconnectedness of the world. How then should corporate policy makers "green" their industries? Porter and Kramer suggest that the focus should be not on the tension between business and society but rather on their interdependence. ${ }^{105}$ They suggest a three-pronged approach: first, identify the points of intersection; second, prioritize the issues to address by focusing on shared values (whether those values are the value chain impacts or social dimensions of competitive context); and third, create a responsive corporate agenda by integrating such values. ${ }^{106}$ Whether this is done by Body Shop's public platform of ecological sustainability and no animal testing, or by BP's rebranding itself as an energy company that is prepared to move "beyond petroleum" and invest in renewable energy, ${ }^{107}$ this integration of value is now a growing corporate trend.

MNCs are not responsible for all the problems, nor do they have the resources to solve them all. But if each can integrate the environment into its business, it can positively affect the sphere of its operations. ${ }^{108}$

\section{Conclusion}

The concept of sustainable development has become the ideological basis of environmental law. The World Commission on Environment and Development defined "sustainable development" as "development that meets the needs of the present with-

105. Michael E. Porter \& Mark R. Kramer, Strategy \& Society: The Link Between Competitive Advantage and Corporate Social Responsibility, HaRv. Bus. Rev., Dec. 2006, at 78, 78.

106. Id. at $84-85,88$.

107. EsTY \& WINSTON, supra note 85 , at $11,252-53$.

108. Porter \& Kramer, supra note 105 , at 92. 
out compromising the ability of future generations to meet their own needs." ${ }^{\prime 09}$ The initial concept of sustainable development was a compromise ${ }^{110}$ between developed and developing countries. Developed countries were lobbying for greater environmental protection, but developing countries wanted their right to development recognized.

We have moved from the "age of frameworks," during which the global community struggled to come to terms with the scale of environmental problems, to the time of finding solutions for them. Whether it is pollution, ozone depletion, or even global warming, we know the issues and there is generally global agreement that the issues must be addressed. What we have yet to decide is how to deal with the issues and who should bear the cost of solving the problems. It seems, therefore, that we are now moving away from the "age of frameworks" to the "age of compliance," in which these general agreements actually have to be implemented.

During the same timeframe, technological advances and trade liberalization have fueled rapid globalization. The rise of sustainable development as a concept, the need for actual implementation of environmental norms, and the phenomenon of rapid globalization have all been major factors with which environmental policy makers must contend.

In 2002, the Johannesburg Summit recognized that globalization need not be demonized, but must rather be harnessed toward the goal of sustainable development. With the increase in wealth maximization as a result of globalization, more resources are available. As the Johannesburg Plan points out, "[g]lobalization offers opportunities and challenges for sustainable development."

By specifically targeting the promotion of corporate responsibility and accountability for sustainable development, the Johannesburg Plan addresses an underdeveloped aspect of the free trade economic model: the need to equitably distribute the extra wealth created by globalization. The primary actors of globalization have been the MNCs. If sustainable development is to succeed, states have to engage these $\mathrm{MNCs}$, and, more importantly, influence their business decisions to take into account sustainable development. In order to achieve this, environmental policies must seek to utilize the motivating factors of "pain, gain, and shame" to integrate the environment into the corporate activities of MNCs. Environmental problems have become global, the actors have become global, and the law must also become global. The influences

109. Our Common Future, supra note 41, at 54.

110. BELL \& MCGILLIVRAY, supra note 19, at 158 ("Specifically, the double-edged quality of the explicit incorporation of developmental concerns. . . might be seen either as an important accommodation of developing world interests or as allowing generally for 'business as usual."').

111. Johannesburg Report, supra note 47, p. 37, \47. 
of MNCs are now far-reaching and their behavior has transboundary repercussions. Environmental law must therefore develop in a legally holistic fashion.

Corporations have gone global in both their reach and their actual presence. These MNCs have greater resources and influence than ever before and have business operations that span across the globe. They are not confined to the sovereign boundaries of states, and as a result, no particular state has enough coercive power to completely regulate the business operations of a particular MNC. Therefore, environmental policy makers should look toward synthesizing all the policy options at their disposal, including those that can be classified as "gain" and "shame," and not just the coercive option of "pain."

It also has become increasingly evident that MNCs can improve the overall performance of their businesses by integrating environmental considerations into their operations. ${ }^{112}$ Examples now abound of how strategic, forward-thinking environmental advice can lead to real strategic business advantages. At the same time, MNCs have also come to realize that they have a significant role to play in environmental protection in the twenty-first century and that they are living in a global environment that has become increasingly fragile.

While the role of the MNC has been emphasized in recent years, the role of the state and the role of the individual in environmental protection will doubtless continue. MNCs are not monolithic entities, but are rather a collection of individual decision makers. At the same time, the corporate entity is a construct of the state. Thus, domestic laws and international treaties which affect individual decision making and state policymaking will still play a major role in ensuring that sustainable development becomes integrated into the world's activities.

The difficulty for environmental policy makers has been, and will continue to be, the conversion of what is usually a short-term profit-orientated actor, the $\mathrm{MNC}$, into an actor that also looks at strategic, long-term sustainable development gains. Nonetheless, as shown above, these are not mutually exclusive characteristics-they merely call for a more holistic and creative approach. After all, over time, MNCs are starting to realize that indeed, no man is an island.

and therefore never send to know for whom the bell tolls; it tolls for thee. ${ }^{113}$

112. The reception of environmental law and awareness by these MNCs has been mixed. See Zarsky \& Tay, supra note 45, at 147 ("Some business groups have embraced the principle of 'social responsibility' which entails a 'triple bottom line': namely, financial, environmental and social concerns. Others fear that raising the bar for environmental performance will disadvantage them in the marketplace.").

113. DONNE, supra note 1 , at 62 . 